\title{
Madness and Revolution: The Impact of Radicalism on the Treason Trial of James Hadfield
}

Austin Nolen

\section{Abstract}

The insanity defense is a doctrine in the criminal law which excuses from punishment defendants who commit crimes as the result of serious mental illness. However, the sorts of mental illness that qualify for the defense, as well as the causal connection required between the illness and the act, have varied widely across Anglo-American legal history. This thesis argues that historians have not sufficiently considered the role that radicalism and social unrest have played in shaping the defense, and explores the 1800 treason trial of James Hadfield for the attempted assassination of King George III, where government fears of the French Revolution and associated English radicals helped to reshape the insanity defense.

\section{Introduction}

On the evening of Thursday, May $15^{\text {th }}, 1800$, the mood in the royal government of the Kingdom of Great Britain was already tense. Earlier in the day, King George III had nearly been shot during a review of the Grenadier Guards' field exercises in Hyde Park. One or more of the Guards had loaded proper ammunition instead of blanks into their muskets, a pay clerk standing near the King had been struck with shot, and the possibility of an assassination attempt had yet to be ruled out. Nevertheless, the royal family decided to attend the theater that night, where the company was performing a comedy called She Would and She Would Not and farce titled The Humorist. ${ }^{1}$

Knowing that the royal family would attend, a large number of the public also attended the play. Most of the crowd likely wanted to gawk at or cheer for their monarch. One of the men in the audience, James Hadfield, had a different plan. He was wearing a soldier's coat with a pistol concealed underneath and was recognizable by the large scar cut across his face. He had also chosen a seat far to the right side of the theater, with an excellent line of sight to the King's raised box on the left-hand side. As soon as the King entered the box, Hadfield sprang onto his seat, drew his pistol, and fired two times

\footnotetext{
${ }^{1}$ Bell's Weekly Messenger (London, England), Sunday, May 18, 1800. Burney Collection, Gale Cengage.
} 
Maneto: The Temple University Multi-Disciplinary Undergraduate Research Journal | 2.1

in the King's direction. ${ }^{2}$

Neither the King nor anyone else was hit, and after a moment of shock, audience members grabbed Hadfield and pushed him over the orchestra barrier where he was taken further back into a room below the stage and interrogated. Meanwhile, the plays began in the theater above, and the audience sang multiple renditions of "God Save the King" after each. Once the theater emptied out, officials swept it for evidence of the ammunition Hadfield had fired. Other officials continued examining witnesses below the stage before committing Hadfield to jail to await trial on a charge of high treason. ${ }^{3}$

The decision to charge Hadfield with treason, instead of charging him with a misdemeanor for shooting randomly or confining him to insane asylum immediately, had consequences. As a result of laws passed by Parliament, treason defendants possessed special rights, including the right to an attorney and a period in which to plan a defense strategy. ${ }^{4}$ Without these rights, Hadfield may have been hanged within the week. Instead, Hadfield had the assistance of skilled counsel when he was tried by a jury on June $26^{\text {th }}, 1800$ in the highest criminal court in England. His defense was able to defeat the clear evidence of the government (no one disputed that Hadfield was the shooter) and win an acquittal by reason of insanity.

To understand the developments in the law of insanity as a result of Hadfield's case, the context of the trial must be understood. Hadfield was not just a single a man with apocalyptic religious beliefs who had attempted to assassinate the head of state. He appeared to government officials to be part of a wave of English radicalism inspired by the French Revolution. Much of this radicalism took explicitly religious and apocalyptic forms. Concerned about Hadfield's motives, the King's Privy Council held a special session to inquire about his political and religious affiliations and gathered some evidence that Hadfield associated with political radicals. Other evidence held by the government suggested a plot to kill the King as well, though some of it had no obvious relation to their prisoner. Thus, the government did not view Hadfield as a minor threat.

Hadfield's beliefs were not the end of his connection to the French Revolution. His alleged insanity stemmed directly from a visible wound in his head that he had sustained in combat against French forces in Europe during the Revolutionary wars. Hadfield's defense exploited this second

\footnotetext{
2 Ibid.

${ }^{3}$ Ibid.

4 “An Act for regulateing of Tryals in Cases of Treason and Misprision of Treason,” 7 Will. 3, c. 3 (1695); “An Act for improving the Union of the Two Kingdoms,” 7 Ann., c. 21 (1708). HeinOnline, Statutes of the Realm Collection.
} 
Maneto: The Temple University Multi-Disciplinary Undergraduate Research Journal | 2.1

connection to portray him as a loyal soldier merely suffering delusions as a result of wounds received in his service and certainly not a threat to the social order.

Despite the rich picture that is gathered from a brief glance at this episode, few scholars have examined the social context of the Hadfield trial or the social history of the insanity defense more broadly. The defense has been shaped not just through the evolution of philosophy, medicine, and the law, but in the context of social unrest. I argue that the government's continuing fears of Hadfield's possible connections to a radical plot foreclosed the possibility that the government would agree to treat Hadfield as insane instead of taking him to trial. As a result, the defense had to introduce a radical innovation into the law of insanity to spare his life. This innovation, the introduction of delusion as a source of insanity, continues to play a role in politically-charged insanity cases today.

\section{Historiography}

In a recent article, Catherine Evans used the phrase "forensic psychiatry studies" to describe "an interdisciplinary field" consisting of "[s]cholars working on criminal insanity, or on the wider themes of mental incapacity or mental condition defences, often rang[ing] widely in training and approach, from jurisprudence to history, sociology to literature."5 Scholars working in these fields focus specifically on legal, medical or cultural developments in the law of insanity. Evans credited criminologist Nigel Walker with writing one of the two foundational texts of forensic psychiatry studies, and in particular with writing the first English history in the field in $1967 .{ }^{6}$ Evans wrote that Walker is not really "invested ... in excavating the cultural and intellectual history of criminal insanity and responsibility," but that he had "a commitment to peering behind the façade of law reports."7 Though Walker uses statistics to move beyond the famous cases, his is still a largely legal history, mostly concerned with the evolution of the law itself and not particularly focused on context.

Subsequent scholars in the field have not sought to displace Walker so much as add social or cultural context to his narrative and to provide more thorough explanations for the trends he chronicles. Most recent historians and other scholars who have tried to elaborate on Walker's work were heavily

\footnotetext{
${ }^{5}$ Catherine L. Evans, “At Her Majesty's Pleasure: Criminal Insanity in $19^{\text {th }}$ Century Britain,” History Compass 14 , no. 10 (2016): 472. doi: 10.1111/hic3.12355.

${ }^{6}$ Ibid., 472-473; Nigel Walker, Crime and Insanity in England, vol. 1, The Historical Perspective (Edinburgh: Edinburgh University Press, 1967).

${ }^{7}$ Evans, “Her Majesty's Pleasure,” 473.
} 
Maneto: The Temple University Multi-Disciplinary Undergraduate Research Journal | 2.1

influenced by French scholar Michel Foucault. This should not be surprising, given Foucault's focus on and influence in the fields of insanity in punishment, developed in texts such as Discipline and Punish and The History of Insanity. These recent contributions also tended to focus heavily on medical and cultural aspects. Foucault himself contributed directly to the historiography of the insanity defense in an article in which he argued that the rise of the insanity defense was linked to increasing claims of expertise by psychiatrists in the courts. ${ }^{8}$

Joel Peter Eigen, another prominent author in the field, attempted to refute Foucault's specific thesis while retaining his focus on power and authority in medicine, and argued that the increasing prominence of psychiatric testimony, in fact, reflected an increased awareness of mental conditions on behalf of defendants and judges, which resulted in increased demand for psychiatric opinions. ${ }^{9}$ In one of the most recent works on the English insanity defense, Dana Rabin adopted an explicitly Foucaultinfluenced thesis, arguing that the increase in insanity pleas in the eighteenth century "accompanied the elaboration and amplification of a wider set of mental excuses ... includ[ing] various mental states that ranged from delirium to confusion. Inside the courtroom the language of excuse reshaped crimes and punishments, signaling a shift in the age-old negotiation of mitigation. Outside the courtroom, the language of the mind reflected society's preoccupation with questions of sensibility, responsibility, and the self." ${ }^{10}$ Medical and cultural questions, in other words, played leading roles in the evolution of the insanity defense.

In 1985, Richard Moran argued that "[m]ost prior analyses of the case of James Hadfield have focused almost exclusively on its legal and medical aspects .... No one has sought to explore the social and historical context in which the special verdict of insanity originated." Moran contended that historians and legal scholars could better understand the evolution of the insanity defense by understanding the particular political and social circumstances surrounding its evolution. ${ }^{11}$ Moran's

\footnotetext{
${ }^{8}$ Michel Foucault, Alain Baudot and Jane Couchman, “About the concept of the 'dangerous individual' in 19th-century legal psychiatry," International Journal of Law and Psychiatry 1, no. 1 (1978): 1-18. doi: 10.1016/0160-2527(78)90020-1.

9 Evans, “Her Majesty's Pleasure,” 473; Richard Moran, “Review of Witnessing Insanity: Madness and Mad-Doctors in the English Court, by Joel Peter Eigen.” American Historical Review 101, no. 4 (1996): 1208-1209. http://www.jstor.org/stable/2169700; Joel Peter Eigen, Witnessing Insanity: Madness and Mad-Doctors in the English Court (New Haven: Yale University Press, 1995).

10 Dana Rabin, Identity, Crime, and Legal Responsibility in Eighteenth-Century England (New York: Palgrave Macmillan, 2004), 2.

11 Richard Moran, "The Origin of Insanity as a Special Verdict: The Trial for Treason of James Hadfield (1800)," Law \& Society Review 19, no. 3 (1985): 489. http://www.jstor.org/stable/3053574.
} 
Maneto: The Temple University Multi-Disciplinary Undergraduate Research Journal | 2.1

emphasis on more traditional political and social analysis has been the exception to the rule, and the Foucault-inspired cultural turn has left unanswered many of the important questions he first raised. Moran included the French Revolution's impact on England among the social conditions he believed to have influenced the Hadfield trial, but that impact is merely one sub-point in his argument. As a result, he did not fully consider how the Revolution and associated radicalism shaped the views of the government and the resulting changes in the law, the topics that this paper focuses on. The cultural turn appears unequipped to answer this more politically-focused question.

For example, one recent article by Neil Ramsey purportedly focusing on the political chaos surrounding the trial of Hadfield primarily described the manner in which these developments resonated in the culture of "sentiment" common in the late eighteenth century. ${ }^{12}$ As a result of this cultural focus, Ramsey overlooked most of the primary sources available for the legal proceedings, including all internal prosecution records, causing him to discount the continuing concern shown in these documents for Hadfield's potential connection to a conspiracy and to rely entirely on other authors for conclusions about the long-term impact of Hadfield's case.

Another recent contribution by Steve Poole did specifically discuss the prosecution's fear of radicalism, but devoted only six pages to Hadfield's case as part of his argument that "assaults against the monarch are most usefully understood within the cultural discourse of petitioning," another cultural argument. ${ }^{13}$ The impact of the prosecution's fear on the development of the actual law of insanity was not analyzed by either Ramsey or Poole. Answering the unsolved questions raised by Moran will contribute to a social history of the insanity defense, which is a necessary complement to medical, cultural and legal histories.

The impact of the French Revolution on England must also be understood to grasp the role radicalism played in Hadfield's trial. Historians have debated for generations the extent to which the English social order was actually threatened by the French Revolution and the English radicals it inspired. ${ }^{14}$ According to Clive Emsley, both nineteenth-century Whig historians and early twentieth century historians such as J. L. and Barbara Hammond claimed that, during the time of the French

${ }^{12}$ Neil Ramsey, “Reframing Regicide: Symbolic Politics and the Sentimental Trial of James Hadfield (1800),” Journal of Eighteenth-Century Studies 36, no. 3 (2013): 317-334. doi: 10.1111/j.1754-0208.2012.00547.x.

${ }^{13}$ Steve Poole, The Politics of Regicide in England, 1760-1850: Troublesome Subjects (New York: Manchester University Press, 2000), 7; 120-125.

${ }^{14}$ Emma Vincent Macleod, “Chapter 9: The Crisis of the French Revolution,” in A Companion to Eighteenth-Century Britain, ed. H. T. Dickinson (Malden, MA: Wiley-Blackwell, 2002), n.p. doi: 10.1111/b.9780631218371.2002.x. 
Maneto: The Temple University Multi-Disciplinary Undergraduate Research Journal | 2.1

Revolution "British reformers and radicals had political arguments intellectually superior to those of their persecutors, and ... that they were moderate and constitutional with only a few eccentric hotheads seeking violent, revolutionary change."15

However, scholars in the middle twentieth century, including E. P. Thompson, emphasized the radical demands made by at least some of those inspired by the Revolution and suggested that "radicalism was by no means always as moderate and constitutionally minded as the Whig interpretation suggested." ${ }^{16}$ Hadfield was no Whig moderate, but how many radicals could he have claimed as fellows? The importance of radicalism to Hadfield's trial is shaped by the answer to that question.

In 1963, Thompson suggested that during the 1790s, radicalism posed a greater threat to the stability of the English order than previously understood. While conceding that radicalism was still a minority view in the late eighteenth century, Thompson traced its evolution and growing influences during the years leading up to Hadfield's act. Prior to the last decade of the century, critics of the government remained "transfixed," he argued, "within the Whiggish limits established by the 1688 settlement" that followed and solidified the outcome of the Glorious Revolution in which William and Mary overthrew James II. The unwritten constitution of the period after 1688 provided every English subject with certain rights, including "freedom from absolutism, ... freedom from arbitrary arrest, trial by jury" and "some limited freedom of thought and conscience."17 But it included no direct say by most English subjects in their own government.

The consensus that largely maintained peace in England after the settlement of 1688 began to crack, Thompson claimed, under the dual weight of the French Revolution and English propagandists such as Thomas Paine. Initially, the revolution was palatable to at least some of the English governing class. Most of the developments from its beginning in 1789 and 1793 were events with precedents in England itself. The revolution began when a fiscal crisis forced King Louis XVI to convoke the Estates General, a representative body similar to the English Parliament. The Third Estate of that body, representing all of France apart from nobles and clergy, then banded together with liberal nobles as the National Assembly to demand an end to absolute rule and the restriction of the King's authority to defined boundaries. Later that year, the Assembly issued the Declaration of the Rights of Man and

\footnotetext{
${ }^{15}$ Clive Emsley, Britain and the French Revolution (New York: Longman, 2000), 4.

${ }^{16}$ Ibid., 5.

17 E.P. Thompson, The Making of the English Working Class, Penguin Modern Classics ed. (New York: Penguin Books, 2013), 86-87.
} 
Maneto: The Temple University Multi-Disciplinary Undergraduate Research Journal | 2.1

Citizen, much like the English Bill of Rights that helped establish the 1688 settlement. The Declaration went further in its concept of universal sovereignty than did England's unwritten constitution, but still remained within the scope of constitutional monarchy. ${ }^{18}$

The Revolution soon began to radicalize, however. In 1792, the National Assembly declared war on monarchical Austria. The German kingdom of Prussia sided with Austria, and the French state became locked in a war with the two absolutist powers. The National Assembly suspended the monarchy and a new body called the National Convention created a republic. That September, a Parisian mob massacred supposed royalist collaborators and in February 1793, Louis XVI was guillotined. ${ }^{19}$ The Revolution set a precedent of "a new constitution drawn up, in the light of reason and from first principles" and including a larger proportion of the public directly in the government of that country. English radicals, most influentially Paine, applied this precedent to their own country, calling for democratic reforms and a leveling of political (though not economic) status. ${ }^{20}$

Thompson recounted that these arguments were then taken up by popular political organizations, such as the London Corresponding Society. The development of mass reform organizations, Thompson claimed, terrified the government. Combined with the increasingly radical developments in France and the Republic's war against other Continental monarchs, "the depth and intensity of the democratic agitation in England" set the government in a hard anti-radical position. Thompson argued that the same "depth and intensity" of protest that alarmed the government was "commonly underestimated" by historians. ${ }^{21}$ A companion to increasing democratic tendencies among the non-property owning class was an increase in millenarian cults. Richard Brothers, for instance, drew a large enough following with prophecies that "'the proud and lofty shall be humbled ... but the righteous and poor shall flourish on the ruins of the wicked"' that he was imprisoned as a lunatic by the English government in $1795 .^{22}$

The public reform organizations such as the LCS were finally crushed in late 1795 when Parliament passed legislation making it a capital crime to hold a mass meeting in defiance of official bans. The legislation was introduced after a crowd of rioters attacked the King's carriage multiple times

18 This account is based on the narrative of the early Revolution in John Merriman, A History of Modern Europe, vol. 1, From the Renaissance to the Age of Napoleon, $2^{\text {nd }}$ ed. (New York: W. W. Norton, 2004), 469-506.

19 Ibid.

20 Thompson, English Working Class, 97-100.

${ }^{21}$ Ibid., 117.

22 Ibid., 128-129. 
Maneto: The Temple University Multi-Disciplinary Undergraduate Research Journal | 2.1

on October $29^{\text {th }}$ of that year. One rioter may have even fired a bullet through one of the carriage windows, leaving a smooth hole in the glass, though the projectile was never located. According to Thompson, however, an increasingly radicalized democratic underground survived the ban, including a modified LCS. ${ }^{23}$

In opposition to Thompson, Linda Colley and other more recent historians have focused less on social conflict in the late eighteenth and early nineteenth centuries than the growing ties binding the various groupings in Britain together. In Britons, Colley investigated "the other side of the picture" from "repression on the one hand and resistance on the other" by studying how a sense of British identity, apart from English, Scottish, Welsh and Irish identities, was fostered in part by the French Revolutionary Wars. In a turn of one of Thompson's phrases, Colley set out to rescue "the seeming conformists ... from the condescension of posterity." 24 Colley's argument with Thompson, however, was not over the specific issue of the government's fears of the LCS and associated radicals. She simply asserted that Thompson's legitimate historical focus on the radicals obscured a broader trend toward union. There is, then, little question that fears of an uprising were on the minds of English officials, even if the extent of that radicalism has been hotly contested in the historiography.

Hadfield was not the first subject to attack George III. In 1786, Margaret Nicholson, a domestic servant, stabbed the monarch with a small knife, and in 1790, John Frith threw a stone at his carriage. In Nicholson's case, officials committed her to an asylum without trial. Frith was charged, but his judges found him insane prior to trial. ${ }^{25}$ Thompson dated the beginning of real worry about English radicalism to $1792-1793$, and the threat had scarcely let up by $1800 .{ }^{26}$ Poole argued that "given the circumstances, and the relatively trivial nature of [Frith's] overt act, there was never any question of [his] being executed for treason," though the situation might have been different had "Frith... thrown his stone in an identical manner after the royal proclamations against sedition in 1792."27 Hadfield's acts, in contrast, came well after royal fears began about French sympathizers, and combined with his possible associations with radicals, the seriousness of his attack, and his capacity to form a plan, evidenced by his decisions to purchase ammunition and to sit in an area of the theater with an excellent

\footnotetext{
23 Ibid., 158-159; 185-188. For details of the riot, see Poole, The Politics of Regicide in England, 103-114.

24 Linda Colley, Britons: Forging the Nation 1707-1837, Nota Bene ed. (New Haven: Yale University Press, 2005), xi; $4-5$.

${ }^{25}$ Walker, Crime and Insanity, 185-186, 223-224.

26 Thompson, English Working Class, 116-117.

27 Poole, The Politics of Regicide in England, 92.
} 
Maneto: The Temple University Multi-Disciplinary Undergraduate Research Journal | 2.1

view of the King, it was unlikely that he would get this treatment. A public hanging was more probable.

It is in this context that we can see how radicalism played an important role in the trial of James Hadfield. Contrary to the emphases of the scholars of the cultural turn, pre-trial records of the prosecution in Hadfield's case show that the government, far from viewing Hadfield only symbolically, continued to view him as part of a threat to the existing order. It was in reaction to this strongly and genuinely perceived threat of revolution, not only against the culture of sentiment and emotion, that the trial unfolded. I argue that the prosecution's concern about a radical plot forced the defense to introduce a novel legal element into the law of insanity, an element with a perennially controversial role in assassination trials. This view of the role of social conflict in changing the insanity defense also assists the reader in more fully understanding more recent changes to the defense as well.

I begin by demonstrating, with internal prosecution records, that fear of a radical plot did not die down in the days immediately following the attack. Unlike the U.S. legal system, the English legal system has long maintained a bifurcation between legal professionals who argue before the courts, barristers, and those who manage the business of representation, solicitors. ${ }^{28}$ The Treasury Solicitor kept the prosecution file and informed the barristers of the facts in a case prosecuted by the Crown. ${ }^{29}$ The files kept by Treasury Solicitor Joseph White, appointed on May $20^{\text {th }}, 1800$ as solicitor for Hadfield's prosecution, form the basis for discerning the government's views on the case. ${ }^{30}$

Next, I demonstrate that because of the continued fear on behalf of the prosecution, the defense could not hope for government mercy, and instead had to introduce a radical new doctrine to spare Hadfield's life. The defense team's decisions can be viewed from two sources: two defense records that were entered into the Treasury Solicitor's files, and the transcript of the trial. While the laws that governed treason trials did not require the prosecution to share its witness list with the defense, this was apparently the standard practice. For instance, one contemporary news report quoted the Attorney General asking the court for an order to send a copy of the list of witnesses to be called against Hadfield along with copies of the indictment and the list potential jurors, which were legally required to be turned over. The senior law officer for the Crown described this as the "usual course.",31

\footnotetext{
28 John H. Langbein, Renée Lettow Lerner, and Bruce P. Smith, History of the Common Law: The Development of Anglo-American Legal Institutions (New York: Aspen Publishers, 2009), 155-164.

29 Ibid., 688.

${ }^{30}$ Letter appointing Joseph White, The National Archives of the United Kingdom (TNA): TS 11/223/937/1, p 155.

${ }^{31}$ Norfolk Chronicle or The Norwich Gazette (London, England), Saturday, May 31, 1800. Burney Collection. “An Act
} 
Maneto: The Temple University Multi-Disciplinary Undergraduate Research Journal | 2.1

The defense appears to have reciprocated by providing a list of witnesses they planned to call and their testimony, as well as a brief outlining the defense's trial strategy. Both records are located in the prosecution files. The trial transcript is located in the State Trials series, which experts consider a source of reliable stenographic accounts by the time of Hadfield's trial. ${ }^{32}$

The National Archives of the United Kingdom maintains White's records of the prosecution in two files, TS 11/223/937/1 and TS 11/223/937/2. These files contain correspondence between members of the government, including high-level officials, depositions and statements taken during the investigation subsequent to the shooting, drafts of government filings, summaries of evidence and other records that reveal the internal thinking of the prosecution team, as well as the select defense records described above. Contemporary news accounts are also used. These records, from the Burney Collection of the British Library, are not as authoritative as the TNA records but help fill in the gaps and establish a context for the archival files. Finally, I demonstrate the continued relevance of the legal innovations at Hadfield's trial and sketch possibilities for future research into the impact of fears of radicalism on the development of the law of insanity.

\section{Prosecution Records}

Government officials began examining witnesses on the night of the shooting, starting with Hadfield. The earliest interrogations, done by officials on hand in the immediate aftermath of the shooting, are not recorded in the Treasury Solicitor's files but were reported in contemporary newspapers. As soon as Hadfield was secured in a chamber below the stage, officials began questioning him. Among the questions they asked were "whether he belonged to the [London] Corresponding Society. He said 'No. He belonged to no political society."' He also firmly denied the existence of any co-conspirators. $^{33}$

A man named Wakelin, who sold Hadfield the pistol he had used, was quickly brought to the theater, questioned and then detained as a possible accomplice. Other witnesses testified as to Hadfield's behavior on the same day prior to the shooting and during the shooting itself. The

for regulateing of Tryals in Cases of Treason and Misprision of Treason” expressly disclaims any requirement to provide a list of government witnesses to treason defendants.

32 John H. Langbein, “The Criminal Trial Before the Lawyers,” The University of Chicago Law Review 45, no. 2 (1978): 265. http://www.jstor.org/stable/1599166.

33 Lloyd's Evening Post, May 14-16, 1800. 17th and 18th Century Burney Collection. 
Maneto: The Temple University Multi-Disciplinary Undergraduate Research Journal | 2.1

newspapers are unclear as to whether these depositions were held in the theater, at the prison Hadfield was confined in that night or some at both, but it is clear that multiple witnesses were informally questioned prior to the start of Privy Council hearings that night. ${ }^{34}$ Moreover, Wakelin was not the only person detained immediately after the shooting. The government also took into custody a man who "hissed" at the King as he left the scene of the shooting, as well as a man who opined that the King would actually be killed in the next attempted assassination. All three were eventually released after interrogation. $^{35}$

Near midnight on the night of the shooting, the King's Privy Council hurriedly arranged a series of hearings held in the office of the Duke of Portland, who was Secretary of State for the Home Department. The Council, together with Justice of the Peace Richard Ford, interrogated witnesses about Hadfield's religious views, his mental condition and his alleged connections with other radicals. ${ }^{36}$ The newspapers are not clear as to whether the Privy Council sat for all of the depositions, but it does appear that for at least a week, Ford operated out of Portland's office, taking depositions on behalf of the Council. ${ }^{37}$

One of the witnesses that the Privy Council interviewed the day after the shooting was James Ede, a clerk for Solomon Houghan, the manufacturer for whom Hadfield also worked. Ede recounted that several days before the shooting, Hadfield told him he had gone to White Conduit Fields to see soldiers flogged, where he met a cobbler named Truelock. Apparently, this Truelock said to Hadfield that "shortly there would be need of no more soldiers, and Jesus Christ was coming, and he would be the only king."38

Later the same day, the Privy Council summoned the same Truelock, whose first name was Bannister. According to Ford's notes of the deposition, Truelock told his interrogators that "Gog and Magog were about to appear very soon, that all kings are then to be put down, and their power taken

${ }^{34}$ Lloyd's Evening Post, May 14-16, 1800; General Evening Post (London, England), May 17-20, 1800. Burney Collection. Wakelin was later released without prosecution.

35 Whitehall Evening Post (1770) (London, England), May 15-17, 1800; Lloyd's Evening Post (London, England), May 19-21, 1800. Burney Collection.

${ }^{36}$ William Cavendish-Bentinck, Third Duke of Portland, was a member of the Privy Council. For the location of the hearings, see Prosecution Brief, pg. 8, TNA TS 11/223/937/2, p 8.

${ }^{37}$ Albion and Evening Advertiser, 26 May 1800. Burney Collection.

${ }^{38}$ Deposition of James Ede, TNA TS 11/223/937/1, p 87-88. 
Maneto: The Temple University Multi-Disciplinary Undergraduate Research Journal | 2.1

away." Ford committed Truelock to the House of Correction as insane on the spot. ${ }^{39}$ The next day, May $17^{\text {th }}$, the Privy Council also called Truelock's wife and father to ask about his character and views. ${ }^{40}$

Ford continued to take depositions on behalf of the prosecution for the next month until just prior to the trial. While some historians of the cultural turn, such as Ramsey, downplay or dismiss any continuing concern by the government about any revolutionary plot after the first few days of depositions, these records in fact reflect a continuing interest by the government in the possibility of Hadfield's connection to radical politics until mere days before the trial.

Despite the fact that both Hadfield and Truelock were now confined, the Privy Council, or at least their agent, Richard Ford, continued inquiring into the radicalism of the two men. On May $23^{\text {rd }}$, the Council sought more testimony on the interaction between Truelock and Hadfield at White Conduit Fields. John Collier, William Luton and Joseph Newman, all of whom knew Truelock, deposed that they had seen Truelock walking with someone they supposed to be Hadfield by the scar on his face near the scene of the flogging. According to these men, Hadfield was "shedding tears." When they asked Truelock why Hadfield was crying, Truelock responded that he had told Hadfield something that greatly upset him. The witnesses recounted that Hadfield had chimed in that, while he was a silversmith, he "should never work anymore." 41

One of the last depositions Ford heard was from Sarah Lock, who testified to officials on May $24^{\text {th }}$, over a week after the shooting. Lock explained that she was Truelock's former landlord, and recounted a number of politically questionable attitudes he had expressed. On one occasion, she said, he "complained of the high price of provisions and said it was owing to the king and government," including Prime Minister William Pitt the Younger, "who were a bunch of thieves." Truelock followed up this inflammatory statement by claiming that "about May or June the king would be assassinated and that we should have no more kings to reign at all" after that. ${ }^{42}$

As the Privy Council testimony neared its end, the government's prosecutors, including Joseph White, met to hash out the indictment they would file against Hadfield. ${ }^{43}$ He had been initially held for a case of high treason, but prosecutors could have decided to withdraw this charge from the formal indictment before trial. Nevertheless, after hearing evidence about his possible radical politics as well

\footnotetext{
39 Deposition of Bannister Truelock, TNA TS 11/223/937/1, p 58-60.

40 Brief of Examinations and Depositions, pg. 13, TNA TS 11/223/937/2, p 29-30.

41 Deposition of John Collier, William Luton and Joseph Newman, TNA TS 11/223/937/1, p 110-111.

42 Deposition of Sarah Lock, TNA TS 11/223/937/1, p 93-94.

43 Notice of Consultation to Settle Indictment, TNA TS 11/223/937/1, p 183-184.
} 
Maneto: The Temple University Multi-Disciplinary Undergraduate Research Journal | 2.1

as his possible insanity, the prosecutors went ahead with an indictment for high treason. This was not the only option open to them: they could have committed Hadfield directly to an insane asylum, as with Margaret Nicholson, or charged him with a misdemeanor for firing randomly. ${ }^{44}$ Hadfield himself claimed that he brought firearms to the theater only to shoot around the King in order to commit suicide by an angry crowd - an admission that could have supported either a misdemeanor charge or a commitment to an asylum, especially considering that other witnesses testified that his desire to die also had a religious dimension. ${ }^{45}$ The government, however, evidently credited the testimony of other theater witnesses that Hadfield had taken direct, steady aim at the King and concluded that Hadfield was not legally insane. ${ }^{46}$ Moreover, they were clearly influenced by fears of his possible association with radicals.

Even after the high government officials closed the hearings and the prosecution confirmed the decision to try Hadfield for high treason, the government continued to seek evidence tying Hadfield and Truelock to a potential radical plot. On May $30^{\text {th }}$, weeks after the shooting and after Hadfield's indictment, Treasury Solicitor White wrote to Justice of the Peace Ford about several outstanding matters in the case, including a request for copies of depositions concerning Truelock that he did not yet have. In the same letter, White also informs Ford that he had "got some information which quite confirms Truelock's landlady's account" of his treasonous statements. ${ }^{47}$

This continued search for information demonstrates that, far from ruling out the possibility of a radical plot early on, the government continued to have fears about that potential up until the trial. This continuing concern is also demonstrated by a brief for the Attorney General prepared by Treasury Solicitor White, which emphasized witnesses "not necessary for proving the indictment, yet it seems

\footnotetext{
44 Moran, “Origin of Insanity,” 493.

45 Deposition of James Hadfield, TNA TS 11/223/937/1, p 46-52. Many witnesses to Hadfield's behavior before and
} after the shooting told investigators that Hadfield claimed he had received a great task from his maker or similar millenarian language, utterances which support an interpretation of the shooting as either religious insanity or as an assassination. For example, one witness records Hadfield saying something like "this is not the worst that is brewing" immediately after the shooting. "Proceedings on the Trial of James Hadfield, at the Bar of the Court of King's Bench, for High Treason, June 26,” in A Complete Collection of State Trials and Proceedings for High Treason and Other Crimes and Misdemeanors From the Earliest Period to the Year 1783, with Notes and Other Illustrations, Vol. 27, 38-40 George III, 1798-1800, edited by Thomas Jones Howell (London: T. C. Hansard, 1820), 1293. http://galenet.galegroup.com.libproxy.temple.edu/servlet/MMLT?af=RN\&ae=Q4200376574\&srchtp=a\&ste=14.

${ }^{46}$ For prosecution witnesses to the shooting, see State Trials, 1293-1300.

47 Letter from Joseph White to Richard Ford, TNA TS 11/223/937/1 p 185-188. 
Maneto: The Temple University Multi-Disciplinary Undergraduate Research Journal | 2.1

proper it should be stated for the information of the counsel for the prosecutor." 48

While the Crown's presentation at trial focused little on evidence tying Hadfield to subversion, this supplemental brief was full of such material. Evidently, Treasury Solicitor White and investigators believed it was important for the prosecutors who would argue the case in court to know about Hadfield's possible radicalism, even though it was not necessary to convict and hang him. The brief contains the examination of Bannister Truelock, his wife, father, and former landlady. It also includes several acquaintances speaking about Truelock's character and the testimony of the constable sent to apprehend Truelock and bring him to the Duke of Portland's office. ${ }^{49}$ The brief also contains two witnesses tending to show a wider conspiracy to assassinate the King. Harriet Rowed, the landlady of a bar, told Crown investigators that she witnessed two men making a toast to the proposition "may he be in his coffin before the morning." She specified that the men did not look like soldiers, suggesting that her examiner might have been trying to determine if the men could have been among the Guards during the incident in Hyde Park where the King was nearly shot. ${ }^{50}$

Charles Jackson likewise told investigators of an encounter he had with a man named Whitcombe in a bar the day of the shooting. When Whitcombe learned of the shooting in Hyde Park, he exclaimed "what does that signify[,] there will be more shots than that," and described the King as "one of the most covetous men in the world." Whitcombe then spoke with one Smith, a shoemaker, whom Jackson described as "a violent Democrat." Smith was one of the men rounded up in the aftermath of the shooting, but he was released after informing on Whitcombe. ${ }^{51}$ The inclusion of these accounts in a report to the chief law officers of the Crown, despite their acknowledged irrelevance to proving Hadfield's guilt, along with the continuing search for new evidence about the political beliefs of the two men, show that the potential for a revolutionary plot remained firmly on the minds of the government officials involved.

\section{The Defense Response}

In light of the undiminished fear by the prosecution of a political plot to kill the King and overthrow the government, as well as the evidence of his client's considered plan to shoot at the King,

\footnotetext{
48 Supplementary Evidence Brief, pg. 1, TNA TS 11/223/937/2, p 1.

49 Supplementary Evidence Brief, pg. 5-6, 8, 12-15, TNA TS 11/223/937/2, p 5-6, 8, 12-15.

50 Supplementary Evidence Brief, pg. 7, TNA TS 11/223/937/2, p 7.

51 Supplementary Evidence Brief, pg. 9, TNA TS 11/223/937/2, p 9.
} 
Maneto: The Temple University Multi-Disciplinary Undergraduate Research Journal | 2.1

Hadfield's chief counsel had no choice but to introduce a radical innovation into the law of insanity. His introduction of the element of delusion in response to these pressures marks the long term impact of the fear of radicalism in Hadfield's case, an impact that continues to play out in the law of insanity today.

Even though Hadfield was tried for treason in a climate of fear and intolerance unlike that faced by Nicholson and Frith, he still had an important advantage against the government. As the result of a series of statutes regulating treason trials passed in the late seventeenth and early eighteenth centuries to end the abuses in treason trials that characterized the reign of the Stuart kings before the Glorious Revolution, he had a number of rights not available to other felony defendants. ${ }^{52}$ One of these was the right to be represented by an attorney, which those accused of other felonies only gained slowly over the nineteenth century. Even better for Hadfield's chances, the law provided that if treason defendants "desire Counsel ... some Judge of that Court shall and is hereby authorized and required immediately upon his or their request to assigne... soe many Counsel not exceeding Two as the Person or Persons shall desire." 53

Though this reads like a modern public defender law, Langbein, Lerner, and Smith argue that this provision of the 1696 act was not designed to provide legal assistance to prisoners, but "to protect defense lawyers from the danger that their work might be treated as conspiracy with the alleged traitors." ${ }^{, 54}$ By the time of Hadfield's trial, however, the provision was operating to effectively provide free counsel to treason defendants. It's unclear whether the defense was required to take the case for free, but at least one contemporary news account assumed defense lawyers would be paid by the government. $^{55}$

Using his rights under the treason statutes, Hadfield hired noteworthy civil liberties attorney Thomas Erskine. Among Erskine's previous clients were Thomas Paine and members of the London Corresponding Society, whom he had successfully defended in political trials. ${ }^{56}$ According to newspaper accounts, Erskine and another attorney whom Hadfield retained, as well as the solicitor he hired, were present in court on the day of his arraignment. Hadfield requested their assistance at that

\footnotetext{
52 Langbein, Lerner, and Smith, History of the Common Law, 661

53 "An Act for regulateing of Tryals in Cases of Treason and Misprision of Treason.”

${ }^{54}$ Langbein, Lerner, and Smith, History of the Common Law, 662.

${ }^{55}$ Albion and Evening Advertiser (London, England), Monday, June 23, 1800. Burney Collection.

${ }^{56}$ Moran, “Origin of Insanity,” 498.
} 
Maneto: The Temple University Multi-Disciplinary Undergraduate Research Journal | 2.1

hearing, an offer the lawyers accepted. ${ }^{57}$ Erskine's mission in light of the case against Hadfield was to introduce a theory of insanity that would remove his client from criminal jeopardy. As a factual brief prepared for Mr. Erskine bluntly stated, "the only defence that can be made for this unhappy defendant is that of insanity." the law insanity at the time of the trial, Hadfield was not insane at the time he committed the offense. After all, the government had witnesses, including Hadfield, suggesting that he was not having a fit on the day of the shooting, that he formulated a conscious plan, buying gunpowder, making ammunition and sitting in an advantageous spot in the theater. Government witnesses also agreed that Hadfield appeared to have shot directly at the King, not around him, as Hadfield claimed.

Though the judge-developed common law of insanity at the time was not precise, swinging between a requirement of that a defendant have a "total deprivation of memory and understanding," and a requirement that the accused have the level of understanding of a child, the facts in Hadfield's case showed that he had an awareness of the nature of the act, and under the law of the time, that he thus had his sanity. As Walker notes, "not only had he planned it in a more or less rational way, but his very objective - to be executed for treason [instead of taking his own life] - showed that he appreciated its probable consequences." 59 If a jury concluded that he had attempted to hit the King, in addition to the other evidence of a plan to which Hadfield admitted, this was enough to execute him.

Instead, Erskine found a way around the old test. As Walker argued, he "resorted to a most skillful tactic. First he undermined the established test by arguing that it could not mean what it said."60 "If a total deprivation of memory was intended ... to be taken in the literal sense of the words," Erskine argued to the jury, "then no such madness ever existed in the world." Instead, he claimed, the test elaborated by the classic common law jurists had to be understood differently. Rather, he told the jury and justices, the true element of insanity is delusion, where "the premises from which [the insane] reason, when within the range of the malady, are uniformly false." In these cases, Erskine claimed, an individual might well have a well thought out plan, yet because the plan is swayed by a strong delusion,

${ }^{57}$ London Chronicle (London, England), June 17-19, 1800. Burney Collection. It is unknown if others were involved in selecting Erskine for the case. In the report cited above, Erskine claimed he was notified that his services would be sought the morning of Hadfield's arraignment, but apparently he did not say by whom. There are suggestions in the prosecution files that some radicals later pressured Hadfield's family to appoint a new solicitor, but Charles Humphries, whom Hadfield originally hired at arraignment, remained on the case. TNA TS 11/223/937/1, p 147-148; State Trials, 1281.

58 Defense Brief, pg. 4, TNA TS 11/223/937/2, p 56.

59 Walker, Crime and Insanity, 77.

60 Ibid. 
Maneto: The Temple University Multi-Disciplinary Undergraduate Research Journal | 2.1

they are insane. ${ }^{61}$

Hadfield's delusion, at least as claimed by the defense, was that he needed to be killed for some religious purpose, but that he could not kill himself. Instead, he wanted his apparent treason to cause others to take his life. Within that delusion, his rational planning was a symptom of insanity, not evidence against it. "Erskine's rhetoric was masterly ... and the flaw in his logic concealed by his sleight of hand," according to Walker. There were more subtle versions of the "total deprivation" test, Walker argued, against which Erskine would have had less success, "but there was no doubt about the effect of his rhetoric ... upon the judges." ${ }^{2}$ Indeed, as Erskine continued to plow through witnesses to Hadfield's other periods of insanity and his delusion, one of the justices inquired if his witness list was nearly exhausted with the thirteen witnesses already examined. "No, my lord," Erskine replied, "I have twenty more witnesses to examine."63 Indeed, a review of the defense witness list in the Treasury Solicitor's file suggests that might have been a conservative estimate. The defense witness list in the prosecution's files contains thirty-seven witnesses, and Erskine called some witnesses not named in that document at trial. ${ }^{64}$

Though Erskine's witnesses could not prove that Hadfield was insane at the moment of the shooting, they could prove his struggles with mental health in other contexts and demonstrate the sway that religious fantasies held over him. They also could testify to his loyal service as a soldier and his continuing expressions of loyalty, undermining the possibility of his involvement in a political plot and further suggesting his delusion as the only possible motivation. Both the defense witness list in the prosecution's files and the trial transcript are replete with witnesses describing Hadfield as a loyal soldier suffering from his wounds. James Ede, whose testimony to the Privy Council led to the arrest of Bannister Truelock, also gave a deposition to the defense. Despite his knowledge of Hadfield's association with Truelock, he told defense investigators that he "considered [Hadfield] a very loyal man."65 At trial, Erskine called several English soldiers to testify to Hadfield's loyalty, including Hercules Macgill, who testified that before Hadfield sustained serious injuries and was left for dead,

61 State Trials, 1313-1314.

${ }^{62}$ Walker, Crime and Insanity, 77-78.

63 State Trials, 1353.

64 Defense Witness List, TNA TS 11/223/937/1, p 13-39. Among the witnesses not listed in this document and who were called at the trial, as recorded in the State Trials volume, were Henry Cline and a Doctor Creighton, two medical professionals who examined Hadfield only the day before the trial.

65 Defense Witness List, pg. 22, TNA TS 11/223/937/1, p 38. 
Maneto: The Temple University Multi-Disciplinary Undergraduate Research Journal | 2.1

"never in my life" did he see Hadfield "hang back from the service of his country."66

This mountain of witnesses, in addition to Erskine's skilled introduction of the argument that Hadfield was insane because of his delusions, was enough: the royal judges virtually directed an acquittal. Though the prosecution had gathered its own mass of evidence suggesting Hadfield was not insane under the old definition at the time of the crime, the Attorney General raised no objection. "If you do run [the case] very nicely," Chief Justice Kenyon told the jury, "be sure it is an acquittal." The Attorney General made sure only to state, falsely, that "the circumstances which have now been stated, [about Hadfield's mental illness] were perfectly unknown to me."67 The jury followed this advice and acquitted Hadfield by reason of insanity.

\section{Conclusion}

The royal government and public maintained fears of Hadfield's potential involvement in a revolutionary plot for a much longer amount of time than previous scholars have noted. Equally unnoticed, this continued fear likely played a role in forcing Erskine to interject the issue of delusion into the law of insanity. While the consequences of this innovation have been studied before, what has been less widely recognized is the extent to which its introduction was the result of fears of radicalism. In this way, late eighteenth-century English radicalism helped to introduce delusion into the insanity defense, still one of its most controversial aspects today.

The question of delusion also colored the case that created the most influential set of rules for judging criminal insanity in the Anglo-American world. On January $20^{\text {th }}$, 1843 , Scottish woodcutter Daniel M'Naghten shot and killed the private secretary to Prime Minister Robert Peel. M'Naghten's attorney argued he had delusions of persecution that compelled him "to commit crimes for which morally he cannot be held responsible." The jury acquitted M'Naghten. While Hadfield's case is legally important for the arguments of counsel and the subsequent reaction of Parliament, discussed below, M'Naghten's is important because of the reaction of the judges. In the ensuing public reaction to the acquittal, the House of Lords put several answers to English judges as to the current state of the law of insanity. The resulting responses, which came to be known as the "M'Naghten rules," provided that, as Walker sums it up, "if the insanity of the accused is limited to a delusion, the only a delusion which, if

\footnotetext{
66 State Trials, 1330-1331.

67 State Trials, 1353-1354.
} 
Maneto: The Temple University Multi-Disciplinary Undergraduate Research Journal | 2.1

true, would have justified his act in law will excuse him from the death penalty." ${ }^{68}$ In other words, the deluded defendant must have imagined a scenario in which he would have been legally justified in his otherwise criminal actions, such as self-defense.

Claims of insanity based on delusions also played a part in the most controversial insanity case of the $20^{\text {th }}$ century: the trial of John W. Hinckley, Jr. for the shooting of President Ronald Reagan. A number of American states had been moving away from the M'Naghten rules starting in the 1950s and 60 s, towards a standard that was somewhat more lenient. Rather than requiring a defendant be absolutely under the sway of a delusion, the new rules excused defendants with "substantial" incapacity to determine the nature of their conduct. It was under this rule that Hinckley was tried, and acquitted, for shooting Reagan as a result of his delusions about actress Jodie Foster. In the aftermath, about half of American state legislatures revised their insanity defense statutes in one way or another to restrict access to the defense. The federal government also adopted a nationwide standard for federal courts for the first time, substantially limiting the reach of the defense in that jurisdiction as well. No new arguments were raised in court; the change in the law was due entirely to legislative reaction. ${ }^{69}$

From Hadfield to M'Naghten to Hinckley, the tendency of those alleged to have committed attacks on the powerful to raise the issue of insanity by delusion seems to be a long-term pattern that shows no sign of abating. Issues of delusion continue to be raised and litigated in the twenty-first century. In Seattle, a man named Christopher Monfort waged a violent campaign for several weeks in 2009 against city police officers, including the murder of one officer and a firebomb attack on police cars. When caught, Monfort's attorneys claimed he was suffering from delusions that his attacks on police officers were an acceptable way to stop police brutality. A jury disagreed and found him guilty of murder in 2015. Though he was spared the death penalty, Monfort, who was paralyzed from the waist down after being shot by his arresting officers, died in prison in $2017 .^{70}$

Monfort's case brings this thesis to an end where it began. I lived in about an hour south of Seattle in Olympia, Washington for several years while his case was in pre-trial proceedings. In May 2015, while on a return visit, I had the opportunity to sit in on a day of the trial in Seattle. As I sat in

\footnotetext{
${ }^{68}$ Walker, Crime and Insanity, 90-100.

69 Peter W. Low, John Calvin Jeffries, Jr. and Richard J. Bonnie, The Trial of John W. Hinckley, Jr.: A Case Study in the Insanity Defense (Mineola, New York: The Foundation Press, 1986), 8-21, 30-34, 126-137.

70 Sara Jean Green, “Prosecutor: Monfort ‘not normal’ but not insane,” The Seattle Times, May 27, 2015, http://www.seattletimes.com/seattle-news/crime/prosecutor-cop-killer-monfort-not-normal-but-not-insane/; “Cause of death for Christopher Monfort won’t be known soon,” The Seattle Times, January 23, 2017, http://www.seattletimes.com/seattlenews/crime/could-be-months-before-cause-of-monforts-death-is-known/.
} 
Maneto: The Temple University Multi-Disciplinary Undergraduate Research Journal | 2.1

court, I listened to prosecution expert witness Dr. Ronald Schouten outline the history and evolution of the insanity defense to the jury. In the context of Monfort's politically charged trial, Schouten's discussion of M'Naghten and Hinckley made me realize that the history of the insanity defense is in many ways the history of society's attempts to protect the powerful from attack. This thesis evolved out of that insight. While I have explored new ground in one small area of this history, much of the story remains untold.

Despite his acquittal on the strength of Erskine's delusion innovation, Hadfield spent the rest of his life in prisons and asylums as the result of laws passed immediately after his trial. These laws made it easier to try suspects accused of attacking the monarch and required the indefinite detention of defendants acquitted on the basis of insanity. Richard Moran made a compelling case that these laws resulted from general fears about instability, in the same manner that he was the first to analyze the Hadfield case as a whole through this lens. ${ }^{71}$ Just as Moran did not specifically explore how radicalism influenced the prosecution, however, he does not explore if and how these same fears specifically influenced this legislation. This is one fruitful area for research going forward, as these laws have had as much impact on the evolution of the insanity defense as the introduction of delusion.

Another potentially important area is the social history of the insanity defense between the great cases. While much of the law has been shaped in and after high profile cases such as Hadfield, M'Naghten and Hinckley, it seems unlikely that it was purely static in the interim. How did concerns over social power impact the evolution of the defense between these cases? Answering this question will lead us to richer understandings of the history of this controversial and obtuse legal institution and will illuminate potential paths that the insanity defense may take in reaction to future social conflict.

71 Moran, “Origin of Insanity,” 513-515. 
Maneto: The Temple University Multi-Disciplinary Undergraduate Research Journal | 2.1

\section{Bibliography}

\section{Primary Sources}

$17^{\text {th }}$ and $18^{\text {th }}$ Century Burney Collection, Gale Cengage

Statutes of the Realm Collection, HeinOnline

The National Archives of the United Kingdom (TNA)

"Proceedings on the Trial of James Hadfield, at the Bar of the Court of King's Bench, for High

Treason, June 26." In A Complete Collection of State Trials and Proceedings for High Treason and Other Crimes and Misdemeanors From the Earliest Period to the Year 1783, with Notes and Other Illustrations. Vol. 27, 38-40 George III, 1798-1800, edited by Thomas Jones Howell. London: T. C. Hansard, 1820. 1281-1356.

\section{http://galenet.galegroup.com.libproxy.temple.edu/servlet/MML}

$\mathrm{af}=\mathrm{RN} \& \mathrm{ae}=\mathrm{Q} 4200376574 \& \operatorname{srchtp}=\mathrm{a} \& \mathrm{ste}=14$.

Secondary Sources:

Colley, Linda. Britons: Forging the Nation 1707-1837. Nota Bene ed. New Haven: Yale University Press, 2005.

Emsley, Clive. Britain and the French Revolution. New York: Longman, 2000.

Evans, Catherine L. “At Her Majesty's Pleasure: Criminal Insanity in $19^{\text {th }}$ Century Britain.” History Compass 14, no. 10 (2016): 470-479. doi: 10.1111/hic3.12355.

Foucault, Michel, Alain Baudot and Jane Couchman. “About the concept of the 'dangerous individual' in 19th-century legal psychiatry." International Journal of Law and Psychiatry 1, no. 1 (1978): 1-18. doi: 10.1016/0160-2527(78)90020-1.

Green, Sara Jean. "Cause of death for Christopher Monfort won't be known soon.” The Seattle Times. January 23, 2017. http://www.seattletimes.com/seattle-news/crime/could-be-months-beforecause-of-monforts-death-is-known/.

—_. "Prosecutor: Monfort 'not normal' but not insane." The Seattle Times. May 27, 2015. http://www.seattletimes.com/seattle-news/crime/prosecutor-cop-killer-monfort-notnormal-but- not-insane/.

Langbein, John H. "The Criminal Trial Before the Lawyers." The University of Chicago Law Review 45, no. 2 (1978): 263-316. http://www.jstor.org/stable/1599166.

Langbein, John H., Renée Lettow Lerner, and Bruce P. Smith. History of the Common Law: The Development of Anglo-American Legal Institutions. New York: Aspen Publishers, 2009. 
Maneto: The Temple University Multi-Disciplinary Undergraduate Research Journal | 2.1

Low, Peter W., John Calvin Jeffries, Jr. and Richard J. Bonnie. The Trial of John W. Hinckley, Jr.: A

Case Study in the Insanity Defense. Mineola, New York: The Foundation Press, 1986.

Macleod, Emma Vincent. "Chapter 9: The Crisis of the French Revolution.” In A Companion to

Eighteenth-Century Britain, edited by H. T. Dickinson, n.p. Malden, MA: Wiley-

Blackwell, ２002. doi: 10.1111/b.9780631218371.2002.x.

Merriman, John. A History of Modern Europe. Vol. 1, From the Renaissance to the Age of Napoleon.

New York: W. W. Norton, 2004.

Moran, Richard. Review of Witnessing Insanity: Madness and Mad-Doctors in the English Court, by Joel Peter Eigen. American Historical Review 101, no. 4 (1996): 1208-1209.

http://www.jstor.org/stable/2169700.

—. "The Origin of Insanity as a Special Verdict: The Trial for Treason of James Hadfield (1800)." Law \& Society Review 19, no. 3 (1985): 487-519.

http://www.jstor.org/stable/3053574.

Poole, Steve. The Politics of Regicide in England, 1760-1850: Troublesome Subjects. New York: Manchester University Press, 2000.

Rabin, Dana. Identity, Crime, and Legal Responsibility in Eighteenth-Century England. New York: Palgrave Macmillan, 2004.

Ramsey, Neil. "Reframing Regicide: Symbolic Politics and the Sentimental Trial of James Hadfield (1800)." Journal of Eighteenth-Century Studies 36, no. 3 (2013): 317-334. doi: 10.1111/j.17540208.2012.00547.x.

Thompson, E. P. The Making of the English Working Class. Penguin Modern Classics ed. New York: Penguin Books, 2013.

Walker, Nigel. Crime and Insanity in England. Vol. 1, The Historical Perspective. Edinburgh: Edinburgh University Press, 1967. 